\title{
PERBEDAAN HASIL BELAJAR MATEMATIKA MENGGUNAKAN MEDIA GAMBAR DENGAN MEDIA KONKRET PADA PELAJARAN GEOMETRI
}

\author{
Annisa Wulandari \\ Fery Rahmawati \\ Universitas Muhammadiyah Palangka raya
}

\begin{abstract}
Abstrak: Penelitian ini bertujuan untuk mengetahui ada tidaknya perbedaan hasil belajar matematika yang pada pembelajarannya menggunakan media konkret dengan media gambar pada peserta didik kelas VI SDN 5 Pahandut Palangka Raya Tahun pelajaran 2012/2013. Metode dalam penelitian ini menggunakan metode Eksperimen dan teknik pengumpulan data dengan menggunakan instrument berupa tes. Populasi penelitian ini adalah seluruh peserta didik kelas VI SDN 5 Pahandut Palangkaraya, yang berjumlah 40 orang peserta didik. Penelitian ini merupakan penelitian populasi. Teknik analisis data yang digunakan adalah uji t. Berdasarkan uji hipotesis diperoleh $t_{\text {hit }}$ sebesar 2,17 sedangkan $t_{\text {tab }}$ pada taraf signifikansi 5\% sebesar 1,690. Dengan demikian $t_{\text {hit }}$ lebih dari dibandingkan $t_{\text {tab }}$ yaitu 2,17 > 1,690, maka Ho ditolak. Jadi terdapat perbedaan hasil belajar matematika antara yang menggunakan media gambar dan media konkret peserta didik kelas VI SDN 5 Pahandut Palangkaraya.
\end{abstract}

Kata kunci: $\quad$ Matematika, Gambar, Media, Konkret, Geometri.

\section{PENDAHULUAN}

Pendidikan pada dasarnya merupakan usaha yang terencana untuk mewujudkan suasana dan proses pembelajaran yang efektif dan efisien bagi peserta didik. Sehingga peserta didik bisa secara aktif mampu mengembangkan potensi yang ada didalam dirinya secara optimal.

Dalam mengembangkan segala potensi yang ada dalam diri peserta didik tersebut bisa terjadi didalam maupun diluar sekolah dan berlangsung seumur hidup. Agar mutu pendidikan dapat tercapai di dalam suatu sekolah, tentunya tidak terlepas dari proses pembelajaran.

Menurut Dimyati dan Mudjiono (2010:297), 'Pembelajaran adalah kegiatan guru secara terprogram dalam desain instruksional untuk membuat siswa belajar secara aktif yang menekankan pada penyediaan sumber belajar". Sesuai dengan pendapat tersebut, maka tindakan pendidik harus terprogram dan sesuai dengan tata cara yang telah ditetapkan sebagai pedoman kegiatan pembelajaran, supaya dapat mempengaruhi peserta didik menuju perubahan tingkah laku yang baik serta tercapai tujuan yang diinginkan.

Setiap proses pembelajaran tentunya mempunyai tujuan tertentu baik bagi peserta didik maupun bagi pendidik. Bagi peserta didik, proses pembelajaran bertujuan untuk memperoleh pengetahuan, sikap dan keterampilan dalam rangka untuk mencapai perubahan tingkah laku yang lebih baik. Sedangkan bagi pendidik, proses pembelajaran bertujuan untuk mengetahui tingkat keberhasilan peserta didik dalam memahami materi yang telah diajarkan. Untuk mengetahui keberhasilan dan kegagalan peserta didik dalam memahami materi yang telah diajarkan, dapat dilihat dari proses peserta didik dalam memahami pelajaran dan juga evaluasi hasil belajar peserta didik.

Banyak jenis media yang bisa digunakan oleh pendidik dalam pembelajaran, yang bisa disesuaikan dengan tujuan yang ingin dicapai dalam pembelajaran tersebut. Media merupakan 
alat bantu untuk menyampaikan pesan yang ingin disampaikan kepada peserta didik. Namun pada kenyataannya banyak pendidik yang jarang menggunakan media didalam pembelajaran. Pendidik lebih banyak berceramah, sehingga pendidik yang lebih aktif dalam pembelajaran. Dan komunikasi hanya terjadi satu arah, pendidik lebih dominan. Peserta didik hanya sebagian saja yang aktif dalam pembelajaran.

Menurut Sudjana dan Rivai (1992), jika dalam setiap proses pembelajaran pendidik menggunakan media yang sesuai dengan materi yang diajarkan, maka peserta didik akan lebih tertarik sehingga dapat menumbuhkan motivasi peserta didik dalam mengikuti pembelajaran.

Evaluasi pada umumnya digunakan sebagai tolak ukur keberhasilan peserta didik dalam belajar serta untuk mengetahui kemajuan belajar peserta didik. Pendapat tersebut sependapat dengan pendapat Dimyati dan Mudjiono(2009:296), yang menyatakan bahwa "evaluasi hasil belajar adalah untuk menentukan nilai belajar siswa melaui kegiatan penilaian dan/atau pengukuran hasil belajar. Dengan proses evaluasi tersebut pendidik dapat mengetahui kemampuan yang dimiliki peserta didik. Media gambar memungkinkan peserta didik untuk dapat melihat dengan jelas apa yang dijelaskan oleh pendidik tanpa ada penafsiran yang salah atau hanya berangan-angan saja. Sedangkan dengan menggunakan media konkret peserta didik bisa menyentuh dan meraba benda yang dijadikan media tersebut.

Dalam memcapai tujuan pembelajaran yang ingin dicapai maka pendidik harus mempunyai cara tertentu agar informasi yang disampaikan dapat diterima oleh peserta didik sesuai dengan yang diharapkan. Penggunaan media sebagai sarana pembelajaran adalah salah satu cara untuk dapat membangkitkan semangat peserta didik dalam belajar dan juga peserta didik akan dapat lebih memahami pelajaran karena media dapat memperjelas penyajian pelajaran. Menurut Kunandar (2009:251) "Hasil belajar adalah kemampuan siswa dalam memenuhi suatu tahapan pencapaian pengalaman belajar dalam satu kompetensi dasar".

Demikian juga pendapat dari Sudjana (2002:110) yang mengatakan bahwa "Hasil Belajar adalah sikap dan tingkah laku yang dinyatakan oleh para siswa setelah menempuh pengalaman belajarnya".

Menurut Depdiknas (2004) menyatakan bahwa banyak pengertian matematika, "Secara Etimologi, perkataan matematika berarti ilmu pengetahuan yang diperoleh dengan bernalar" dalam buku tersebut juga menyatakan bahwa bukan berarti ilmu lain tidak diperoleh dengan bernalar akan tetapi matematika lebih menekankan pada penalaran atau aktifitas dalam dunia rasio, sedangkan ilmu lain lebih menekankan pada hasil observasi dan eksperimen disamping dengan penalaran.

Menurut Rodhatul Jennah (2009:1) kata media berasal dari bahasa latin medius yang secara harfiah berarti 'tengah, perantara, atau pengantar. Dalam bahasa Arab media adalah perantara atau pengantar pesan dari pengirim kepada penerima pesan".

Jadi media dari segi pembelajaran merupakan sarana yang sangat membantu proses belajar mengajar dalam penyampaian pesan kepada peserta didik, dan juga dapat merangsang peserta didik untuk belajar sehingga dapat tercapai tujuan pembelajaran yang ingin dicapai. Menurut Sudjana dan Rivai (2002:196) menyatakan bahwa 'Menggunakan bendabenda nyata dalam pembelajaran seringkali paling baik dalam menpilkan benda-benda nyata tentang suatu ukuran, suara, gerakgerik, permukaan, bau serta manfaatnya". Menurut Rodhatul Jennah (2009:62) "Gambar adalah media visual yang berupa goresan-goresan, coretan-coretan atau bentuk-bentuk lain yang dapat menimbulkan tanggapan, persepsi ataupun pemikiran manusia terhadap objek atau 
benda tertentu". Media gambar tidak harus digambar secara manual, foto, poster juga termasuk media gambar. Hal tersebut sesuai dengan pendapat Hamzah (2010:119) "Gambar didefinisikan sebagai representasi visual dari orang, tempat ataupun benda yang diwujudkan diatas kanvas, kertas, atau bahan lain, baik dengan cara lukisan, gambar atau foto".

Melalui penggunaan media peserta didik akan lebih termotivasi dan dapat membantu merangsang keaktifan di dalam proses pembelajaran. Dalam pembelajaran matematika, media juga sangat diperlukan. Matematika adalah salah satu pelajaran yang memerlukan pemikiran yang logis dan penalaran sehingga media memegang peranan yang sangat penting dalam proses pembelajaran.

Pada pelajaran geometri, akan lebih mudah tercapainya tujuan pembelajaran apabila dilakukan dengan menggunakan media yang tepat. Media gambar dan media konkret menjadi beberapa alternative dalam pembelajaran matematika khususnya geometri yang berhubungan dengan bangun ruang.

Menurut Nana Sudjana (2002:193) menyatakan bahwa "Media konkret termasuk ke dalam media benda nyata yang keberadaannya dapat dipandang dari segala arah dan diraba bentuknya". Sesuai dengan pendapat tersebut diatas media konkret merupakan alat bantu pmbelajaran yang keberadaannya bisa dilihat, diraba, dan disentuh oleh peserta didik yang digunakan untuk menyampaikan pesan sehingga peserta didik menjadi termotivasi dan bersemangat dalam belajar.

\section{METODOLOGI}

Penelitian ini dilaksanakan di SDN 5 Pahandut Palangkaraya pada semester ganjil tahun ajaran 2012 /2013. Yang beralamat di jalan Pepaya Palangka Raya.

Metode penelitian eksperimen yang digunakan adalah model Randomized Subject pretest posttest control group Design. Dalam model ini kita harus menentukan dua kelas, yang pertama kelas eksperimen1 dan yang kedua adalah Kelas Eksperimen2. Dimana kelas experimen1 akan mendapatkan pembelajaran dengan menggunakan media konkret sebagai media pembelajarannya. Sedangkan pada Kelas Eksperimen2 menggunakan media gambar sebagai media pembelajarannya.

Eksperimen menurut Arikunto (3013:3) adalah suatu cara untuk mencari sebap akibat (hubungan kausal) antara dua faktor yang sengaja ditimbulkan oleh peneliti dengan mengurangi atau menyisihkan faktor-faktor lain yang bisa mengganggu. 'Dalam penelitian eksperimen ada perlakuan (tratmen) metode penelitian digunakan untuk mencari pengaruh perlakuan tertentu terhadap yang lain dalam kondisi yaang terkendali (sugiono, 2013:72).

Populasi merupakan sekumpulan objek sejenis yang menjadi target generalisasi penelitian. Pendapat tersebut sesuai dengan pendapat Nurul Zuriah (2009:116) yang mengatakan bahwa "populasi adalah seluruh data yang menjadi perhatian peneliti dalam suatu ruang lingkup dan waktu yang ditentukan".

Pendapat ahli maka dapat disimpulkan bahwa populasi adalah keseluruhan dari objek yang akan diteliti. Maka populasi penelitian disini adalah seluruh peserta didik kelas VI A dan VI B SDN 5 Pahandut Palangka Raya tahun ajaran 2012/ 2013 yang berjumlah 40 orang. Pengumpulan data merupakan salah satu bagian yang penting dalam suatu penelitian. Untuk mengumpulkan data penelitian, maka teknik yang digunakan dalam penelitian ini adalah Tes. Tes disini digunakan untuk mengukur aspek kognitif peserta didik.

\section{HASIL DAN PEMBAHASAN}

Instrumen yang digunakan dalam penelitian ini adalah tes. Tes yang digunakan adalah soal berbentuk pilihan ganda yang disusun oleh peneliti yang mengacu pada Kurikulum Tingkat Satuan Pendidikan(KTSP). Untuk menguji 
instrumen dengan validitas isi, peneliti meminta bantuan dua validator, yaitu salah satu dosen Universitas Muhammadiyah Palangkaraya dan guru mata pelajaran Matematika di SDN 5 Pahandut.

Tabel 1. Hasil Analisis Pre-test subjek penelitian:

Kelas A (Pre)

\begin{tabular}{|c|c|c|c|}
\hline No & $\begin{array}{c}\text { Kode } \\
\text { Peserta } \\
\text { didik }\end{array}$ & $\begin{array}{c}\text { Nilai } \\
\text { Pretes }\left(\mathrm{X}_{1}\right)\end{array}$ & $\left(\mathrm{X}_{1}\right)^{2}$ \\
\hline 1 & 01 & 5 & 25 \\
\hline 2 & 02 & 2.5 & 6.25 \\
\hline 3 & 03 & 7.5 & 56.25 \\
\hline 4 & 04 & 7 & 49 \\
\hline 5 & 05 & 5 & 25 \\
\hline 6 & 06 & 6 & 36 \\
\hline 7 & 07 & 7 & 49 \\
\hline 8 & 08 & 3.5 & 12.25 \\
\hline 9 & 09 & 3 & 9 \\
\hline 10 & 10 & 2.5 & 6.25 \\
\hline 11 & 11 & 3.5 & 12.25 \\
\hline 12 & 12 & 4.5 & 20.25 \\
\hline 13 & 13 & 7.5 & 56.25 \\
\hline 14 & 14 & 4 & 16 \\
\hline 15 & 15 & 5 & 25 \\
\hline 16 & 16 & 4.5 & 20.25 \\
\hline 17 & 17 & 8 & 64 \\
\hline 18 & 18 & 8.5 & 72.25 \\
\hline 19 & 19 & 3 & 9 \\
\hline 20 & 20 & 4.5 & 20.25 \\
\hline & JUMLAH & 102 & 589.5 \\
\hline
\end{tabular}

Kelas B (Pre)

\begin{tabular}{|c|c|c|c|}
\hline No & $\begin{array}{c}\text { Kode Peserta } \\
\text { didik }\end{array}$ & $\begin{array}{c}\text { Nilai Pretes } \\
\left(\mathrm{X}_{2}\right)\end{array}$ & $\left(\mathrm{X}_{2}\right)^{2}$ \\
\hline 1 & 01 & 6 & 36 \\
\hline 2 & 02 & 3 & 9 \\
\hline 3 & 03 & 6.5 & 42.25 \\
\hline 4 & 04 & 6 & 36 \\
\hline 5 & 05 & 4.5 & 20.25 \\
\hline 6 & 06 & 2.5 & 6.25 \\
\hline 7 & 07 & 3 & 9 \\
\hline 8 & 08 & 5 & 25 \\
\hline
\end{tabular}

\begin{tabular}{|c|c|c|c|}
9 & 09 & 4.5 & 20.25 \\
\hline 10 & 10 & 5 & 25 \\
\hline 11 & 11 & 7 & 49 \\
\hline 12 & 12 & 3 & 9 \\
\hline 13 & 13 & 8 & 64 \\
\hline 14 & 14 & 7 & 49 \\
\hline 15 & 15 & 4 & 16 \\
\hline 16 & 16 & 5.5 & 30.25 \\
\hline 17 & 17 & 4.5 & 20.25 \\
\hline 18 & 18 & 3 & 9 \\
\hline 19 & 19 & 5 & 25 \\
\hline 20 & 20 & 4 & 16 \\
\hline & JUMLAH & 97 & 516.5 \\
\hline
\end{tabular}

Berdasarkan hasil perhitungan diatas, nilai $t_{\text {hitung }}<t_{\text {tabel }}$ sehingga Ho diterima dan Ha ditolak. Maka dapat disimpulkan bahwa pada pre-tes kelas VIa dan VIb yang dilakukan peneliti pada mata pelajaran Matematika tidak terdapat perbedaan kemampuan awal, yang artinya hasil belajar Matematika peserta didik kelas VIa dan VIb layak untuk dibandingkan karena memiliki kemampuan awal yang relatif sama.

Tabel 2. Hasil Analisis Post Test subjek penelitian:

Kelas A (Post)

\begin{tabular}{|c|c|c|c|}
\hline No & $\begin{array}{c}\text { Kode } \\
\text { Peserta } \\
\text { didik }\end{array}$ & Nilai $\left(X_{1}\right)$ & $\left(\mathrm{X}_{1}\right)^{2}$ \\
\hline 1 & 01 & 8.5 & 72.25 \\
\hline 2 & 02 & 7 & 49 \\
\hline 3 & 03 & 9 & 81 \\
\hline 4 & 04 & 9.5 & 90.25 \\
\hline 5 & 05 & 9 & 81 \\
\hline 6 & 06 & 8 & 64 \\
\hline 7 & 07 & 9 & 81 \\
\hline 8 & 08 & 9.5 & 90.25 \\
\hline 9 & 09 & 6 & 36 \\
\hline 10 & 10 & 7.5 & 56.25 \\
\hline 11 & 11 & 7.5 & 56.25 \\
\hline 12 & 12 & 8.5 & 72.25 \\
\hline 13 & 13 & 7 & 49 \\
\hline
\end{tabular}




\begin{tabular}{|c|c|c|c|}
14 & 14 & 4.5 & 20.25 \\
\hline 15 & 15 & 7 & 49 \\
\hline 16 & 16 & 9.5 & 90.25 \\
\hline 17 & 17 & 9.5 & 90.25 \\
\hline 18 & 18 & 7.5 & 56.25 \\
\hline 19 & 19 & 9.5 & 90.25 \\
\hline 20 & 20 & 6 & 36 \\
\hline & JUMLAH & 159.5 & 1310.75 \\
\hline
\end{tabular}

Kelas B (Post)

\begin{tabular}{|c|c|c|c|}
\hline No & $\begin{array}{c}\text { Kode Peserta } \\
\text { didik }\end{array}$ & $\begin{array}{c}\text { NILAI } \\
\mathrm{X} 2 \\
\end{array}$ & $(\mathrm{X} 2)^{2}$ \\
\hline 1 & 15 & 7.5 & 56.25 \\
\hline 2 & 14 & 7 & 49 \\
\hline 3 & 14 & 7 & 49 \\
\hline 4 & 14 & 7 & 49 \\
\hline 5 & 12 & 6 & 36 \\
\hline 6 & 11 & 5.5 & 30.25 \\
\hline 7 & 15 & 7.5 & 56.25 \\
\hline 8 & 18 & 9 & 81 \\
\hline 9 & 16 & 8 & 64 \\
\hline 10 & 14 & 7 & 49 \\
\hline 11 & 15 & 7.5 & 56.25 \\
\hline 12 & 12 & 6 & 36 \\
\hline 13 & 18 & 9 & 81 \\
\hline 14 & 14 & 7 & 49 \\
\hline 15 & 12 & 6 & 36 \\
\hline 16 & 11 & 5.5 & 30.25 \\
\hline 17 & 18 & 9 & 81 \\
\hline 18 & 16 & 8 & 64 \\
\hline 19 & 15 & 7.5 & 56.25 \\
\hline 20 & 10 & 5 & 25 \\
\hline JUMLAH & 284 & 142 & 1034.5 \\
\hline
\end{tabular}

Berdasarkan tabel 8 dan tabel 9 diperoleh hasil, dari kelas VIa (eksperimen) dengan jumlah 20 orang peserta didik memiliki nilai rata-rata $\left(\bar{X}_{1}\right)$ $=7,98$ dan variansi $\left(S_{1}^{2}\right)=1,93$. sedangkan pada kelas VIb (eksperimen2) dengan jumlah 20 peserta didik diperoleh nilai rata-rata $\left(\bar{X}_{2}\right)=7,1$ dan variansi $\left(\mathrm{S}_{2}{ }^{2}\right)$ $=1,31$.

Berdasarkan penelitian yang telah peneliti lakukan di SDN 5 Pahandut tentang penggunaan media pembelajaran, yakni media kokret dan media gambar pada pembelajaran matematika, ada perbedaan hasil belajar peserta didik antara penggunaan kedua media tersebut.

Penggunaan media yang tepat merupakan salah satu langkah yang bisa dilakukan oleh pendidik agar peserta didik memperoleh hasil belajar yang lebih baik. Media juga menjadikan peserta didik menjadi termotivasi untuk belajar dan dapat memusatkan perhatian peserta didik agar lebih terfokus pada pelajaran/ materi yang diajarkan.

Penggunaan media konkret memberikan pengalaman secara langsung kepada peserta didik dalam pembelajaran, karena peserta didik dapat dengan jelas melihat dan menyentuh benda-benda yang dijadikan media pembelajaran. Dengan media konkret peserta didik juga menjadi lebih tertarik untuk memperhatikan/ menyimak pelajaran yang diberikan oleh guru sehingga penyerapan materi menjadi lebih maksimal.

Berdasarkan data yang telah diperoleh, yang telah diuji dengan mengguakan uji $\mathrm{t}$ diperoleh hasil $\mathrm{t}$ hitung lebih dari t tabel. T hitung sebesar 2,17 sedangkan $\mathrm{t}$ tabel sebesar 1,90. Jadi $\mathrm{t}_{\text {hit }}>$ $\mathrm{t}_{\text {tab }}$ yaitu $2,17>1.90$. Sehingga terdapat perbedaan hasil belajar matematika peserta didik antara yang menggunakan media konkret dan media gambar pada materi geometri kelas VI SDN 5 Pahandut.

Penjelasan tersebut dapat disimpulkan bahwa hasil belajar peserta didik antara yang menggunakan media konkret dalam pembelajarannya, lebih baik dibandingkan dengan yang menggunakan media gambar pada peserta didik kelas VI SDN 5 Pahandut.

Adapun kelemahan dalam penelitian ini adalah kesamaan pada instrumen pretest dan posttest, yang mengakibatkan ada kemungkinan peserta didik bisa menjawab soal posttest tersebut dengan benar disebabkan oleh faktor 
bawaan karena soal tersebut pernah diberikan sebelumnya pada uji kemampuan prasyarat (pretest). Kelemahan lain dari penelitian ini adalah tidak semua variabel dapat dikontrol, maksudnya banyak hal dapat mempengaruhi hasil belajar Matematika peserta didik seperti, minat, tingkat intelektual, lingkungan keluarga dan kesehatan peserta didik. Dimana setiap peserta didik antara yang satu dengan yang lainya memiliki perbedaan. Sedangkan dalam penelitian ini peneliti hanya mengontrol pada aspek penggunaan media pembelajaran yang sering digunakan guru dalam proses pembelajaran Matematika, akibatnya ada kemungkinan hasil belajar Matematika peserta didik dipengaruhi oleh faktor lain.

\section{PENUTUP}

Berdasarkan pengujian hipotesis yang terdapat pada bab IV tentang hasil belajar matematika peserta didik kelas VI SDN 5 Pahandut antara yang menggunakan media konkret dan media gambar, dapat disimpulkan bahwa ada perbedaan hasil belajar Matematika peserta didik antara yang menggunakan media konkret dan media gambar di SDN 5 Pahandut Palangkaraya. Hasil perhitungan dengan menggunakan uji $t$ diperoleh hasil yaitu $t_{\text {hitung }}$ sebesar 2,17 dan $t_{\text {tabel }}$ sebesar 1.90. Sehingga $t_{\text {hit }}>t_{\text {tab }}$

Berdasarkan nilai rata-rata yang diperoleh peserta didik kelas VIa yang menggunakan media konkret yaitu 7,97, sedangkan rata-rata nilai pada kelas VIb yang menggunakan media gambar adalah 7,1. Artinya hasil pembelajaran Matematika peserta didik kelas VI SDN 5 Pahandut Palangkaraya yang diajarkan dengan menggunakan media konkret lebih baik dibandingkan dengan pembelajaran yang menggunakan media gambar.

\section{DAFTAR PUSTAKA}

Azhar Arsyad, 2007, Media Pembelajaran, Jakarta: Raja Grafindo Persada
Daryanto, (2011), Media Pembelajaran, Bandung: Sarana Tutorial Nurani Sejahtera

Departeemen pendidikan Nasional, (2006),

Kurikulum Tingkat Satuan

Pendidikan Sekolah Dasar,

Jakarata: Tim penyusun

Departemen Pendidikan Nasional, (2008),

Kreatifitas Guru dalam

pembelajaran, Jakarta: Balai pustaka

Dian Safarina (2013) Perbedaan Hasil Belajar Ipa Peserta Didik Kelas $V$ Sdn - 6 Langkai Palangka Raya Antara Yang Menggunakan Media Konkret Dengan Yang Menggunakan Media Gambar Tahun Pelajaran 2012/2013, Universitas Muhammadiyah Palangkaraya.

Dimyati, Mudjiono, (2009), Belajar dan Pembelajaran, Jakarta, Rineka Cipta

Hamdani, (2011), Dasar-dasar Kependidikan, Bandung: Pustaka setia

Hamzah B Uno, (2010), Profesi Pendidikan, Jakarta: Sinar Grafika Offset

Kunandar, (2009), Guru Profesional, Jakarta: Rajawali Pers

Moh.Nazir, (2005), Metode penelitian, Bogor: Ghalia Indonesia

Muhammad Zainal Abidin (2013), http://www.masbied.com/search/ definisi-geometri 02 Februari 2013

Mukhtar \& Martinis Yamin, (2007), 10 Kiat Sukses Mengajar di Kelas, Jakarta: PT Nimas Multima.

Nurul Zuriah, (2009), Metodologi Penelitian Sosial dan Pendidikan, Jakarta: Rineka Cipta

Oemar Hamalik, (2009), Proses Belajar Mengajar, Jakarta: Sinar Grafika Offset

Pupuh Fathurohman, Sobry Sutikno, (2007), Strategi Belajar 
Mengajar, Bandung: PT Refika aditama

Purwa Atmaja P, (2012), Psikologi pendidikan, Bandung: Ar Ruzz Media

Rodhatul Jennah, (2009), Media Pembelajaran, Banjarmasin: Antasari Press

Sardiman, Arief Dr, 2007, Media pendidikan, Jakarta: Raja Grafindo Persada

Sri Rahayu (2009), Penerapan Media Konkret (nyata) dalam pembelajaran Matematika pada Peserta Didik Kelas IV di SDN-5 Palangka Raya, Universitas Muhammadiyah Palangkaraya.

Sri Ratu Kartini, (2012), Perbedaan hasil belajar IPA antara yang menggunakan media nyata dengan yang menggunakan media gambar peserta didik kelas $V$ SDN-8 Menteng Palangka Raya, Universitas Muhammadiyah Palangk araya

Sri Winarti, (2010), Efektifitas Pembelajaran dengan Menggunakan Pendekatan Tematik pada peserta didik SDN 11 Langkai, Palangka Raya

Sudjana, N (2004), Dasar-dasar Belajar mengajar, Bandung: Sinar baru Algensindo

Sudjana,N \& Ahmad Rivai, (2002), Media Pengajaran, Bandung: Sinar Baru algensindo

Sugiyono, 2006, Statistika Untuk Penelitian, Bandung: CV Alfabeta

Suharsimi Arikunto, (2006), Prosedur Penelitian, Jakarta: Rineka Cipta

Sukardi, 2009, Metodologi Penelitian Pendidikan, Jakarta: Bumi Aksara.

Sumadi Suryabrata, S, (2010), Metodologi Penelitian, Jakarta: PT Raja Grafindo Persada

Suyono \& Hariyanto, (2011), Belajar dan pembelajaran, Bandung : Remaja Rosdakarya
Syaiful Bahri Djamarah dan Aswan Zain, (2010), Strategi Belajar mengajar, Jakarta: Rineka Cipta

Tim Penyusun, (2012), Buku Pedoman Penulisan Skripsi FKIP Universitas Muhammadiyah, Palangka Raya, Universitas Muhammadiyah 